\title{
TLR ligands and cytokines induce CXCR3 ligands in endothelial cells: enhanced CXCL9 in autoimmune arthritis
}

\author{
Tamara Loos ${ }^{1}$, Lies Dekeyzer ${ }^{1}$, Sofie Struyf ${ }^{1}$, Evemie Schutyser ${ }^{1}$, Klara Gijsbers ${ }^{1}$, \\ Mieke Gouwy ${ }^{1}$, Annelies Fraeyman ${ }^{1}$, Willy Put ${ }^{1}$, Isabelle Ronsse ${ }^{1}$, Bernard Grillet ${ }^{2, *}$, \\ Ghislain Opdenakker ${ }^{2}$, Jo Van Damme ${ }^{1}$ and Paul Proost ${ }^{1}$ \\ ${ }^{1}$ Laboratory of Molecular Immunology, Rega Institute for Medical Research, University of Leuven, Leuven, \\ Belgium and ${ }^{2}$ Laboratory of Immunobiology, Rega Institute for Medical Research, University of Leuven, \\ Leuven, Belgium
}

\begin{abstract}
CXC chemokines are potent attractants of neutrophil granulocytes, T cells or natural killer cells. Toll-like receptors (TLR) recognize microbial components and are also activated by endogenous molecules possibly implicated in autoimmune arthritis. In contrast to CXC chemokine ligand 8 (CXCL8), no CXC chemokine receptor 3 (CXCR3) ligand (ie CXCL9, CXCL10 and CXCL11) was induced by bacterial TLR ligands in human microvascular endothelial cells (HMVEC). However, peptidoglycan (PGN), double-stranded (ds) RNA or lipopolysaccharide (LPS) (TLR2, TLR3 or TLR4 ligands, respectively) synergized with interferon- $\gamma$ (IFN- $\gamma$ ) at inducing CXCL9 and CXCL10. In contrast, enhanced CXCL11 secretion was only obtained when IFN- $\gamma$ was combined with TLR3 ligand. Furthermore, flagellin, loxoribine and unmethylated CpG oligonucleotide (TLR5, TLR7 and TLR9 ligands, respectively) did not enhance IFN- $\gamma$-dependent CXCR3 ligand production in HMVEC. In analogy with TLR ligands, tumor necrosis factor- $\alpha$ (TNF- $\alpha$ ) or interleukin-1 $\beta$ (IL-1 $\beta$ ), in combination with IFN- $\gamma$, synergistically induced CXCL9 and CXCL11 in HMVEC and human fibroblasts, two fundamental cell types delineating the joint cavity. Etanercept, a humanized soluble recombinant p75 TNF-receptor/lgG, Fc fusionprotein, neutralized synergistic CXCL9 production induced by TNF- $\alpha$ plus IFN- $\gamma$, but not synergy between IFN- $\gamma$ and the TLR ligands PGN or LPS. Synovial chemokine concentrations exemplify the fysiopathological relevance of the observed in vitro chemokine production patterns. In synovial fluids of patients with spondylarthropathies (ie ankylosing spondylitis or psoriatic arthritis) or rheumatoid arthritis, significantly enhanced CXCL9, but not CXCL11 levels, were detected compared to concentrations in synovial fluids of patients with metabolic crystal-induced arthritis. Thus, CXCL9 is an important chemokine in autoimmune arthritis.
\end{abstract}

Laboratory Investigation (2006) 86, 902-916. doi:10.1038/labinvest.3700453; published online 17 July 2006

Keywords: ankylosing spondylitis; autoimmunity; chemokines; CXCR3; psoriatic arthritis; Toll-like receptors

Chemokines are low molecular mass chemotactic cytokines and are predominantly classified as CC or CXC chemokines, depending on the position of the first two conserved cysteine residues. CC and CXC chemokine receptors (CCR and CXCR, respectively) belong to the group of seven-transmembrane spanning G-protein-coupled receptors. ${ }^{1,2}$ Each chemokine attracts and activates specific leukocyte subclasses. ${ }^{3}$ A number of chemokines, for example,

Correspondence: Dr P Proost, PhD, Laboratory of Molecular Immunology, Rega Institute for Medical Research, University of Leuven, Minderbroedersstraat 10, Leuven 3000, Belgium.

E-mail: paul.proost@rega.kuleuven.be

${ }^{*}$ Current address: Ziekenhuis Zeeuws-Vlaanderen, Terneuzen, The Netherlands.

Received 23 February 2006; revised 22 May 2006; accepted 15 June 2006; published online 17 July 2006
CXCL12 (stromal cell-derived factor-1 $\alpha /$ SDF-1 $\alpha$ ), are constitutively produced, and play a crucial role in lymphocyte or dendritic cell homing processes. ${ }^{4-8}$ However, other chemokines, for example, CXCL8 (interleukin-8/IL-8), are only produced upon stimulation of cells with cytokines or microbial products such as Toll-like receptor (TLR) ligands, and hence play a crucial role in inflammation.

The microvascular endothelium and chemokines not only play a crucial role in inflammation, but also in angiogenesis. ${ }^{9}$ Chemokines constitute a peculiar family of angiogenesis modulators compared to growth factors, for example, fibroblast growth factor, since chemokines may exert angiogenic or antiangiogenic properties. In contrast to the angiogenic CXCL8 which binds to CXCR1 and CXCR2, CXCL4 (platelet factor-4/PF-4), CXCL4 variant and the 
CXCR3 ligands CXCL9 (monokine induced by interferon- $\gamma$ (IFN)/Mig), CXCL10 (IFN- $\gamma$-inducible protein-10/IP-10) and CXCL11 (IFN-inducible T-cell $\alpha$-chemoattractant/I-TAC) have antiangiogenic activities. ${ }^{9,10}$ However, the exact mechanism of action of chemokines in the angiogenic process is not known. Angiogenesis is a hallmark for tumor growth and autoimmune diseases, for example, rheumatoid arthritis. ${ }^{11,12}$ A number of chemokines produced by endothelial cells are implicated in autoimmune diseases such as rheumatoid arthritis, multiple sclerosis and psoriasis. ${ }^{13}$ Certain chemokine receptors, for example, CXCR2, ${ }^{9}$ are expressed on endothelial cells, but also proteoglycan interactions may influence the angiogenic response. ${ }^{14}$ The production of CXCR2 and CXCR3 ligands by endothelial cells upon stimulation with individual cytokines or microbial products has been reported. ${ }^{15}$ Moreover, endothelial cells express TLR2, 3, 4, 5 and 9, but not TLR7, nor TLR8. ${ }^{16-19}$ TLR are wellknown to bind microbial components. ${ }^{20,21}$ In addition, TLR play a role in B-cell responses and recognize endogenous substances, for example, necrotic cells, fibronectin fragments and hyaluronan oligosaccharides, indicative for their possible role in the pathogenesis of chronic inflammatory diseases, for example, rheumatoid arthritis, psoriasis, ankylosing spondylitis, Crohn's disease, ulcerative colitis and atherosclerosis. ${ }^{22-25}$

In pathological conditions, for example, during a bacterial infection, endothelial cells are simultaneously stimulated with cytokines and TLR ligands. Moreover, the IL-1R and TLR use common signal transduction pathways. ${ }^{26}$ Cotreatment of cells with different stimuli, for example, IFN- $\gamma$ plus TLR ligands, may result in a cell-specific chemokine production both quantitatively and qualitatively. ${ }^{27,28}$ Little information is available on the combined effect of cytokines and TLR ligands on the production of angiogenic and antiangiogenic chemokines by human microvascular endothelial cells (HMVEC). To define novel interactions in the regulation of chemokine balances, we evaluated both the relative and absolute amounts of CXCL8, CXCL9, CXCL10 and CXCL11 protein produced by HMVEC upon stimulation with IFN- $\gamma$ in combination with a representative panel of microbial TLR ligands. In addition, we compared CXCL9 and CXCL11 production by HMVEC and fibroblasts in response to cytokine combinations. Finally, CXCL9 and CXCL11 concentrations in synovial fluids of patients with autoimmune rheumatic disorders were examined.

\section{Materials and methods}

\section{Reagents}

Recombinant human IL- $1 \beta$, tumor necrosis factor- $\alpha$ (TNF), IFN- $\gamma$, CXCL9 and CXCL10 were purchased from PeproTech (Rocky Hill, NJ, USA). Recombinant
IFN- $\alpha$ (Roferon A) was from Hoffman-La Roche (Nutley, NJ, USA) and IFN- $\beta$ (Avonex) was from Biogen (Cambridge, MA, USA). Human CXCL11 was obtained from R\&D Systems (Minneapolis, MN, USA). Natural human CXCL8 was purified from conditioned medium of leukocytes. ${ }^{29}$ Bacterial peptidoglycan (PGN) from Staphylococcus aureus and the double-stranded RNA (dsRNA) polyriboinosinic:polyribocytidylic acid (polyrI:rC) were from Sigma-Aldrich (St Louis, MO, USA). Bacterial lipopolysaccharide (LPS) from Escherichia coli 0111:B4 was purchased from Difco Laboratories (Detroit, MI, USA) and recombinant E. coli flagellin was from Inotek Pharmaceuticals (Beverly, MA, USA). The TLR7 ligand loxoribine (7-allyl-8-oxoguanosine), the TLR9 ligand unmethylated cytosine guanosine dinucleotide $(\mathrm{CpG})$ oligonucleotide ODN2006 (sequence: $5^{\prime}$-tcgtcgttttgtcgttttgtcgtt-3') and its control unmethylated GpC oligonucleotide ODN2006 Co (sequence 5 '-tgctgcttttgtgcttttgtgctt-3') were obtained from Invivogen (San Diego, CA, USA). Endotoxin levels were checked with the limulus amoebocyte lysate assay (Cambrex Bio Science, Verviers, Belgium) and were $<30 \mathrm{pg}$ LPS/mg for PGN and $<600 \mathrm{pg} \mathrm{LPS} / \mu \mathrm{g}$ for flagellin. The preparation of recombinant human IFN- $\gamma$ contained $<1 \mathrm{pg}$ LPS $/ \mu \mathrm{g}$. Endotoxin levels in IFN- $\alpha$ and IFN- $\beta$ samples were $<2 \mathrm{pg} \mathrm{LPS} / 10^{6} \mathrm{U}$ of IFN. Etanercept $\left(\right.$ Enbrel $^{\mathbb{R}}$ ) was purchased from Wyeth Pharmaceticals (Madison, NJ, USA) and the neutralizing monoclonal anti-human IL-1 $\beta$ was from R\&D Systems.

\section{Cell Cultures and Induction Experiments}

Human dermal neonatal microvascular endothelial cells (Cambrex Bio Science) from pooled donors were cultured to confluency in endothelial basal medium (EBM-2; Cambrex Bio Science), supplemented with the endothelial growth medium EGM2MV SingleQuots (Cambrex Bio Science). Cells grown in 48-well microtiter plates were induced for 24 or $72 \mathrm{~h}$ in $0.5 \mathrm{ml}$ of medium with cytokines and/or TLR ligands 5 days after subcultivation. Human diploid skin/muscle-derived fibroblasts (E1SM) were grown in Eagle's minimal essential medium (EMEM; Cambrex Bio Science) containing $10 \% \mathrm{FBS}^{27,28}$ Monolayers were grown to confluency in 24-well dishes and inducers were added to $1 \mathrm{ml}$ of medium 5 days after subcultivation. Conditioned media were harvested after $72 \mathrm{~h}$.

\section{Patient Samples}

Synovial fluids from patients were collected in dry tubes, centrifuged at 1000 r.p.m. for $4 \mathrm{~min}$, aliquoted and immediately frozen at $-20^{\circ} \mathrm{C}$ until analysis (Table 1). Rheumatoid arthritis patients fulfilled the revised American College of Rheumatology criteria for rheumatoid arthritis. Ankylosing spondylitis patients were diagnosed according to the modified 
New York criteria and were all HLA-B27 positive. Crystal-induced arthritis was diagnosed when in the synovial fluid either uric acid or calcium pyrophosphate dihydrate was detected by polarized light microscopy. Psoriatic arthritis was defined as arthritis in patients with psoriasis. All procedures followed the tenets of the Declaration of Helsinki, and informed consent was obtained from all

Table 1 Arthritis patients

\begin{tabular}{lcccr}
\hline & $\mathrm{N}$ & Male/female & $\begin{array}{c}\text { Age (years) } \\
\text { range (mean) }\end{array}$ & $\begin{array}{r}\text { Sed. }{ }^{\mathrm{a}}(\mathrm{mm} / \mathrm{h}) \\
\text { range (mean) }\end{array}$ \\
\hline $\mathrm{PsA}^{\mathrm{b}}$ & 14 & $13 / 1$ & $16-60(39.0)$ & $6-92(21.0)$ \\
$\mathrm{AS}^{\mathrm{c}}$ & 18 & $14 / 4$ & $21-71(32.0)$ & $6-135(34.5)$ \\
$\mathrm{CA}^{\mathrm{d}}$ & 24 & $17 / 7$ & $28-81(59.5)$ & $4-99(30.0)$ \\
$\mathrm{RA}^{\mathrm{e}}$ & 75 & $27 / 48$ & $13-79(61.0)$ & $4-120(47.5)$ \\
\hline
\end{tabular}

${ }^{\mathrm{a}}$ Sedimentation rate of erythrocytes.

${ }^{\mathrm{b}}$ Psoriatic arthritis.

${ }^{\mathrm{c}}$ Ankylosing Spondylitis.

${ }^{\mathrm{d}}$ Crystal-induced arthritis.

${ }^{\mathrm{e}}$ Rheumatoid arthritis. patients. The study was approved by the Ethical Committee of the University of Leuven.

\section{Immunoassays}

Specific ELISA to quantify CXCL8, CXCL9, CXCL10 and CXCL11 were developed in our laboratory as previously described. ${ }^{27,28}$ These ELISA did not show crossreactivity with any other chemokine or any used chemokine inducer. Statistical comparison between synergistic production levels and the sum of singly induced chemokine concentrations was performed using the Mann-Whitney test on paired values. Mean chemokine concentrations \pm s.e. of the mean are provided in Supplementary Tables 1-4 at Laboratory Investigation's website.

\section{Results}

\section{Bacterial TLR Ligands Differentially Induce CXC Chemokines in HMVEC}

IFN- $\gamma$ is known to induce CXCR3 ligands in several cell types during infection or inflammation. ${ }^{30,31}$ In

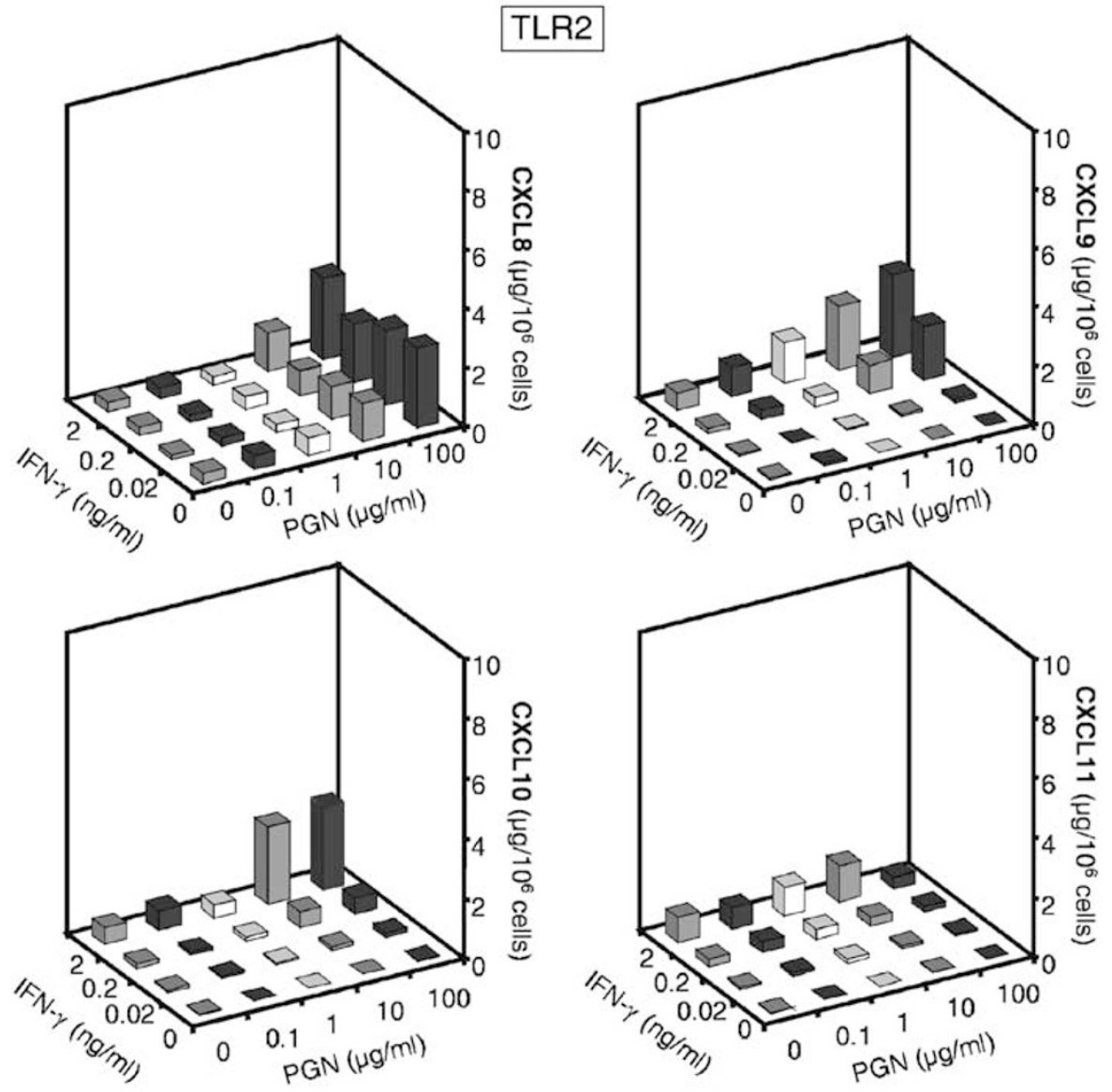

Figure 1 Differential induction of CXC chemokines in HMVEC by IFN- $\gamma$ in combination with a TLR2 ligand. Confluent HMVEC were incubated for $72 \mathrm{~h}$ with IFN- $\gamma$ in combination with bacterial PGN. Results represent the mean CXCL8, CXCL9, CXCL10 and CXCL11 concentration measured by ELISA in the culture supernatant (three or more independent experiments). For clarity, error bars were not depicted in the figure. Significant synergistic induction of CXCL9 and CXCL10 was already obtained at $2 \mathrm{ng} / \mathrm{ml}$ of IFN- $\gamma$ in combination with $10 \mu \mathrm{g} / \mathrm{ml}$ of PGN $(P<0.05)$. 

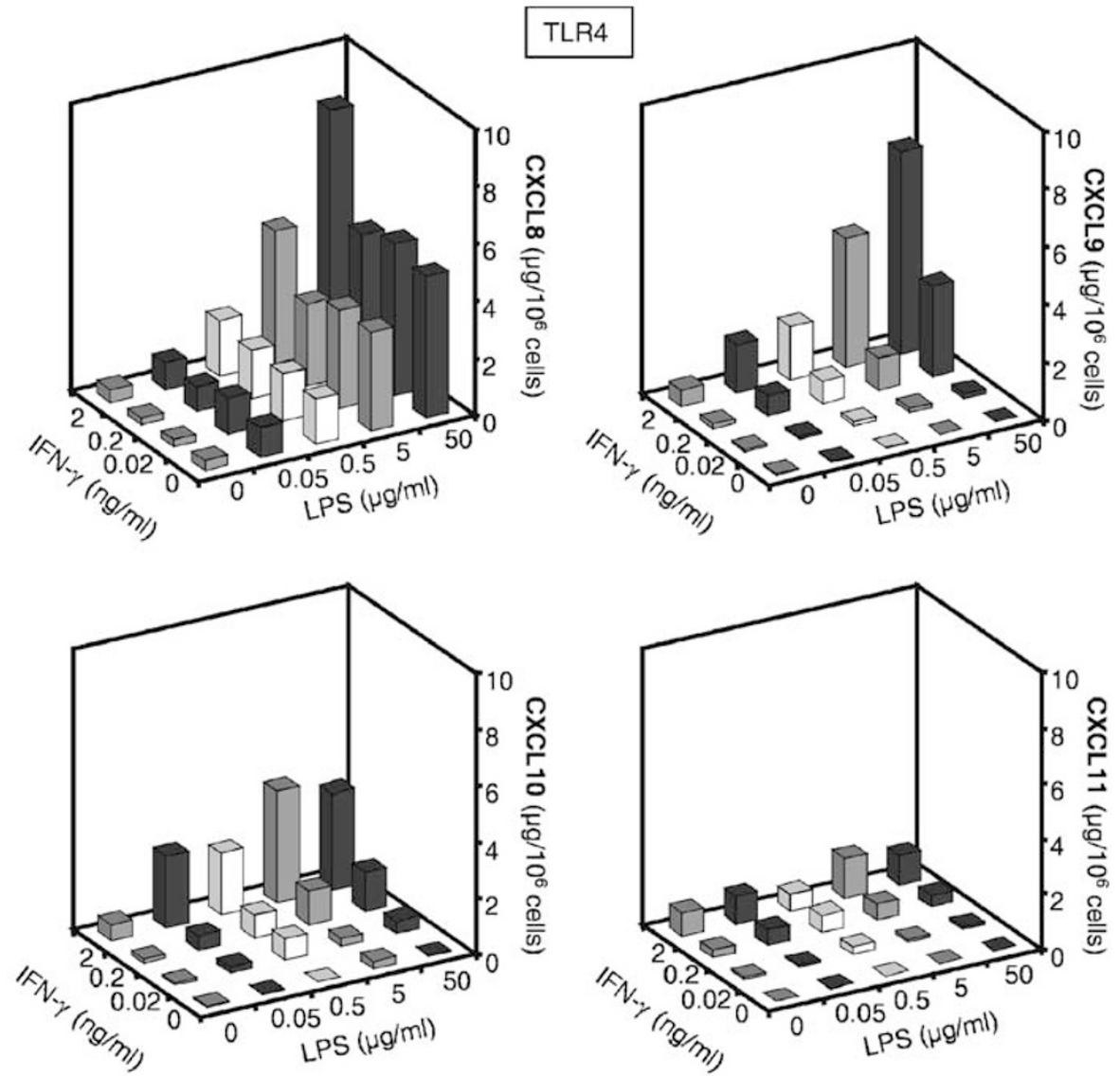

Figure 2 Differential induction of CXC chemokines in HMVEC by IFN- $\gamma$ in combination with a TLR4 ligand. Results represent the mean CXCL8, CXCL9, CXCL10 and CXCL11 concentration measured in the culture supernatant after incubating confluent HMVEC with IFN- $\gamma$ in combination with bacterial LPS for $72 \mathrm{~h}$ (three or more independent experiments). For clarity, error bars were not depicted in the figure. Significant synergistic induction of CXCL9 and CXCL10 was already obtained at $2 \mathrm{ng} / \mathrm{ml}$ of IFN- $\gamma$ in combination with $0.5 \mu \mathrm{g} / \mathrm{ml}$ of LPS $(P<0.05)$ and $0.05 \mu \mathrm{g} / \mathrm{ml}$ of LPS $(P<0.001)$, respectively.

HMVEC, more than $500 \mathrm{ng}$ of CXCL9, CXCL10 and CXCL11, but no CXCL8, was produced per $10^{6}$ cells in $72 \mathrm{~h}$ upon stimulation with $2 \mathrm{ng} / \mathrm{ml}$ of $I F N-\gamma$ (Figure 1).

Gram-positive bacteria possess a cell wall which consists of a highly organized layer of PGN, recognized by TLR2. ${ }^{32}$ In HMVEC, $100 \mu \mathrm{g} / \mathrm{ml}$ of PGN induced more than $3 \mu \mathrm{g}$ per $10^{6}$ cells of CXCL8, but no CXCR3 ligands (Figure 1). The PGN-induced CXCL8 production was not affected when HMVEC were cotreated with IFN- $\gamma$. However, PGN dosedependently increased the IFN- $\gamma$-induced production of CXCL9 and CXCL10, but not CXCL11. Significant synergistic induction of CXCL9 and CXCL10 was obtained at $2 \mathrm{ng} / \mathrm{ml}$ of IFN- $\gamma$ in combination with $10 \mu \mathrm{g} / \mathrm{ml}$ of PGN $(P<0.05)$ and in combination with $100 \mu \mathrm{g} / \mathrm{ml}$ of PGN $(P<0.01$ and $P<0.001$, respectively). The effect of PGN was not dependent on LPS contamination, since the PGN sample contained $<3 \mathrm{pg}$ LPS $/ 100 \mu \mathrm{g}$ of PGN.

The TLR4 ligand LPS is a major component of the outer membrane of Gram-negative bacteria. ${ }^{33}$ In HMVEC, LPS was a strong inducer of CXCL8 ( $>4 \mu \mathrm{g} / 10^{6}$ cells), but again no significant difference was observed when IFN- $\gamma$ was added to the TLR4 ligand (Figure 2). In parallel with PGN, LPS did not induce CXCR3 ligands in HMVEC. However, when LPS was applied in combination with IFN- $\gamma$, a strong synergistic effect was observed with on average a 16and 10-fold increased CXCL9 and CXCL10 production, respectively, compared to stimulation of the HMVEC with IFN- $\gamma$ alone. Significant synergistic induction of CXCL9 was obtained at $2 \mathrm{ng} / \mathrm{ml}$ of IFN- $\gamma$ in combination with $0.5 \mu \mathrm{g} / \mathrm{ml}$ of LPS $(P<0.05)$. Synergistic CXCL10 production was observed from $0.2 \mathrm{ng} / \mathrm{ml}$ of IFN- $\gamma$ in combination with $0.05 \mu \mathrm{g} / \mathrm{ml}$ of LPS $(P<0.05)$ up to $2 \mathrm{ng} / \mathrm{ml}$ of IFN- $\gamma$ in combination with $50 \mu \mathrm{g} / \mathrm{ml}$ of LPS $(P<0.001)$. Again, no synergy between LPS and IFN- $\gamma$ was obtained for CXCL11 induction.

Finally, flagellin was evaluated as a third compound of bacterial origin. ${ }^{34}$ Unlike TLR2 and TLR4 ligands, this TLR5 ligand did not induce CXCL8 (Figure 3). Similar to TLR2 and TLR4 ligands, no CXCR3 agonists were produced by flagellin-stimulated HMVEC. Flagellin was also unable to significantly increase the IFN- $\gamma$-dependent induction of CXCL9, CXCL10 or CXCL11. 

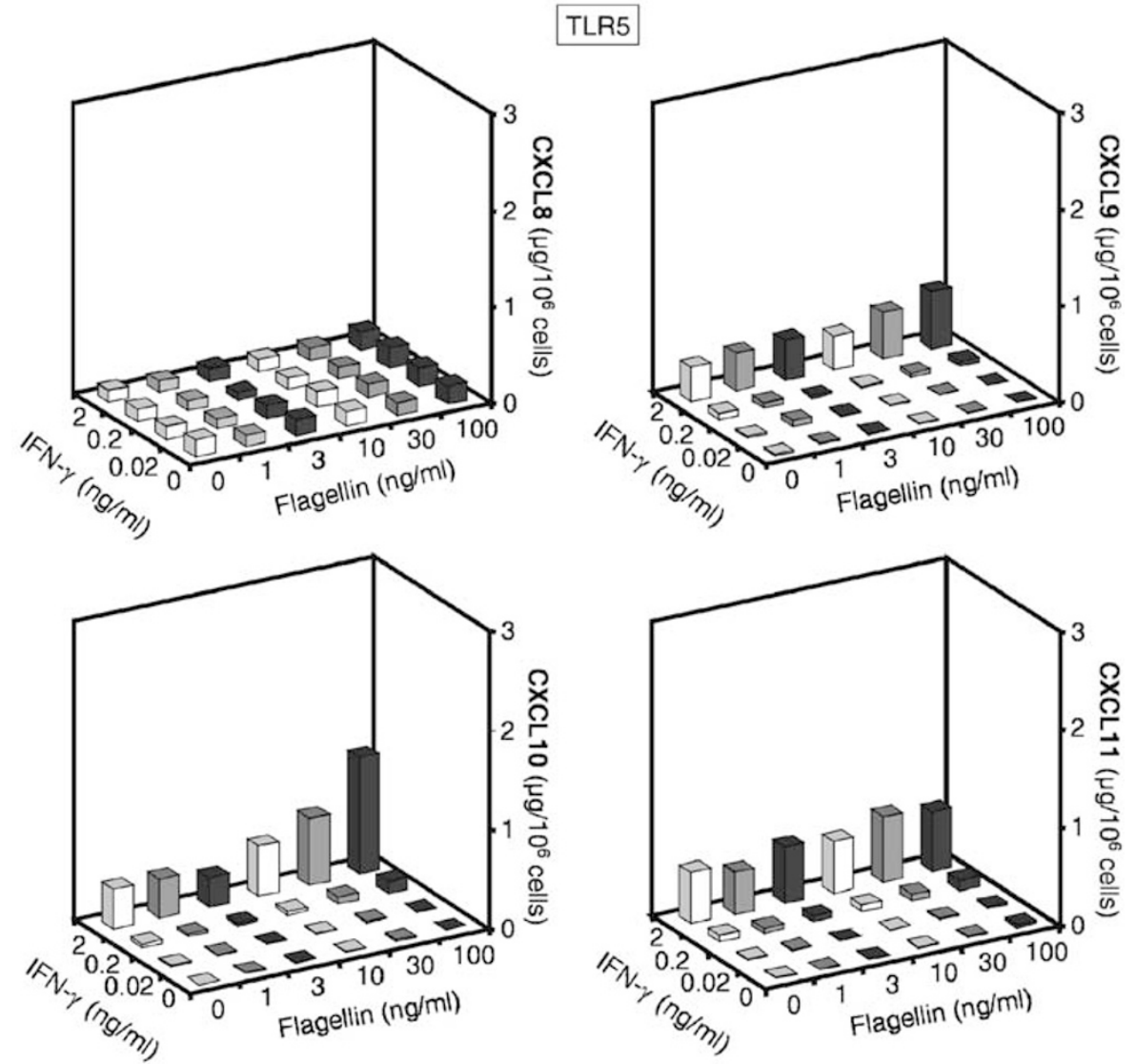

Figure 3 Differential induction of CXC chemokines in HMVEC by IFN- $\gamma$ in combination with a TLR5 ligand. HMVEC were cultured to confluency and incubated for $72 \mathrm{~h}$ with IFN- $\gamma$ in combination with bacterial flagellin. Results represent the mean CXCL8, CXCL9, CXCL10 and CXCL11 concentration measured in the culture supernatant (four or more independent experiments). For clarity, error bars were not depicted in the figure.

\section{Viral TLR Ligands Differentially Induce CXC Chemokines in HMVEC}

As a consequence of viral infection, $\mathrm{T}$ lymphocytes produce IFN- $\gamma$, directing an upregulation of class I MHC surface molecules on surrounding endothelial cells. During replication, some viruses produce dsRNA which is recognized by TLR3. ${ }^{35}$ In HMVEC, the dsRNA polyriboinosinic:polyribocytidylic acid (polyrI:rC) alone dose-dependently provoked a strong induction of CXCL8 ( $>2.5 \mu \mathrm{g} / 10^{6}$ cells) and, in contrast to bacterial TLR ligands, also induced the production of CXCL10 and CXCL11, but not CXCL9 (Figure 4). Synergy between IFN- $\gamma$ and the TLR3 ligand was observed for all three CXCR3 agonists, but not for CXCL8. Remarkably, CXCL11 was produced at similar concentrations compared to CXCL10 and CXCL9. Significant synergistic production of CXCL9, CXCL10 and CXCL11 was obtained upon stimulation with $2 \mathrm{ng} / \mathrm{ml}$ of IFN $-\gamma$ in combination with $10 \mu \mathrm{g} / \mathrm{ml}(P<0.01), 0.01 \mu \mathrm{g} / \mathrm{ml}(P<0.05)$ and $1 \mu \mathrm{g} / \mathrm{ml}$ of dsRNA $(P<0.01)$, respectively. This suggests that CXCL9 and CXCL10 are mainly mediators in bacterial infection, whereas CXCL11 seems more relevant for activation of CXCR3 during infection with RNA viruses.
Recently, the synthetic disubstituted guanosine nucleoside loxoribine, was shown to establish its activities through TLR7. ${ }^{36}$ In HMVEC, loxoribine could not stimulate production of CXCL8 or CXCR3 ligands, nor could it enhance production of CXCR3 agonists induced by IFN- $\gamma$ (Figure 5).

\section{Inhibition of CXCR3 Ligand Production by HMVEC upon Stimulation with Unmethylated CpG Oligonucleotide does not Reside in TLR9 Activation}

Complementarily to previous experiments, we investigated whether the IFN- $\gamma$-induced production of CXCR3 agonists was altered by administrating a TLR9 ligand, that is, unmethylated CpG oligonucleotide. $^{37}$ The IFN- $\gamma$-induced CXCR3 ligand production in HMVEC was inhibited by the CpG oligonucleotide (Figure 6). To assess the actual TLR9 interference, we performed similar experiments using the unmethylated $\mathrm{GpC}$ oligonucleotide as a negative control. Remarkably, inhibition of the chemokine production was also observed in this set of experiments in HMVEC (Figure 6), although no toxicity was observed (data not shown). These results indicate that the mechanism responsible for 

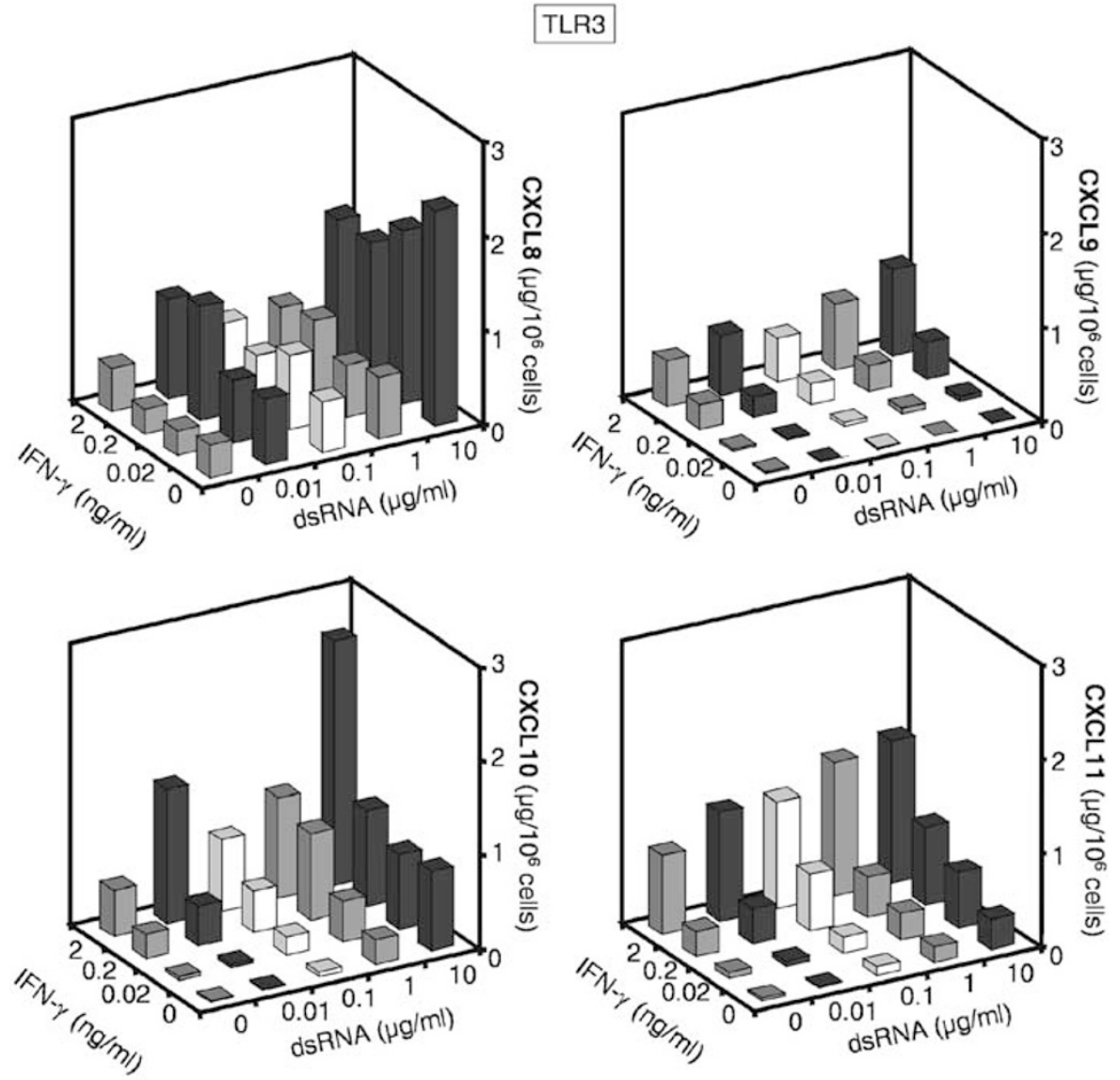

Figure 4 Differential induction of CXC chemokines in HMVEC by IFN- $\gamma$ in combination with a TLR3 ligand. Results represent the mean CXCL8, CXCL9, CXCL10 and CXCL11 concentration measured in the culture supernatant after incubating confluent HMVEC with IFN- $\gamma$ in combination with the dsRNA polyriboinosinic:polyribocytidylic acid (polyrI:rC) for $72 \mathrm{~h}$ (four or more independent experiments). For clarity, error bars were not depicted in the figure. Significant synergistic induction of CXCL9, CXCL10 and CXCL11 was obtained at $2 \mathrm{ng} /$ $\mathrm{ml}$ of IFN- $\gamma$ in combination with $10 \mu \mathrm{g} / \mathrm{ml}(P<0.01), 0.01 \mu \mathrm{g} / \mathrm{ml}(P<0.05)$ and $1 \mu \mathrm{g} / \mathrm{ml}$ of dsRNA $(P<0.01)$, respectively.

the observed inhibitory effect of the unmethylated CpG oligonucleotide on chemokine induction in HMVEC seems not TLR9-mediated.

\section{TLR Ligands Interfere with IFN- $\gamma$-Induced CXCR3 Ligand Production by HMVEC}

To exclude whether the observed synergy resulted from cytokines induced by the tested TLR ligands, we analyzed CXCR3 ligand induction in HMVEC within $24 \mathrm{~h}$. A significant synergistic CXCL9 and CXCL10 induction $(P<0.05)$ was already observed by $0.05 \mu \mathrm{g} / \mathrm{ml}$ of LPS combined with $2 \mathrm{ng} / \mathrm{ml}$ of IFN- $\gamma$ (Figure 7). Synergistic CXCL10 production was also obtained when HMVEC were stimulated with $0.2 \mathrm{ng} / \mathrm{ml}$ of IFN- $\gamma$ in combination with $0.05 \mu \mathrm{g} / \mathrm{ml}$ of LPS $(P<0.05)$ and with $5 \mu \mathrm{g} / \mathrm{ml}$ of LPS $(P<0.05)$. These results suggest a direct effect for TLR ligands (other data not shown) on the IFN- $\gamma$-induced CXCR3 ligand production in HMVEC. Moreover, combinations of IFN- $\gamma(0.02-2 \mathrm{ng} / \mathrm{ml})$ and IFN- $\beta(10-1000 \mathrm{U} /$ $\mathrm{ml}$ ) did not result in synergistic induction of CXCR3 ligands (data not shown).

\section{Differential Induction of CXCL9 and CXCL11 by Inflammatory Cytokines in HMVEC and Fibroblasts}

Stimulation of macrophages with TLR4 ligand (LPS) causes production of TNF- $\alpha$ and IL- $1 \beta$, which in turn activate endothelial cells resulting in increased cytokine secretion and enhanced expression of ICAM. Moreover, TLR and the IL-1R have common signal transduction pathways. ${ }^{26}$ For these reasons, we examined chemokine induction by IFN in combination with IL- $1 \beta$ or TNF- $\alpha$ in HMVEC (Figure 8). Our findings concerning CXCL8 production (data not shown) were consistent with previous reports, in that a synergistic effect was observed for CXCL8 when HMVEC were stimulated with IL- $1 \alpha$ and IFN$\gamma{ }^{38}$ Cotreatment of HMVEC with IFN- $\gamma$ and IL- $1 \beta$, which did not induce CXCR3 ligands by itself, resulted in a synergistic production of CXCL9 (Figure 8). Indeed, $2 \mathrm{ng} / \mathrm{ml}$ of IFN- $\gamma$ synergized with $1 \mathrm{ng} / \mathrm{ml}$ of IL- $1 \beta$ in inducing about $2 \mu$ g of CXCL9 per $10^{6}$ cells $(P<0.05)$. TNF- $\alpha$ induced CXCL9 and some CXCL11 in HMVEC, but in combination with IFN- $\gamma$, high levels of CXCL9 $\left(7 \mu \mathrm{g} / 10^{6}\right.$ cells $)(P<0.05)$ were produced, comparable to those reached by IFN- $\gamma$ 

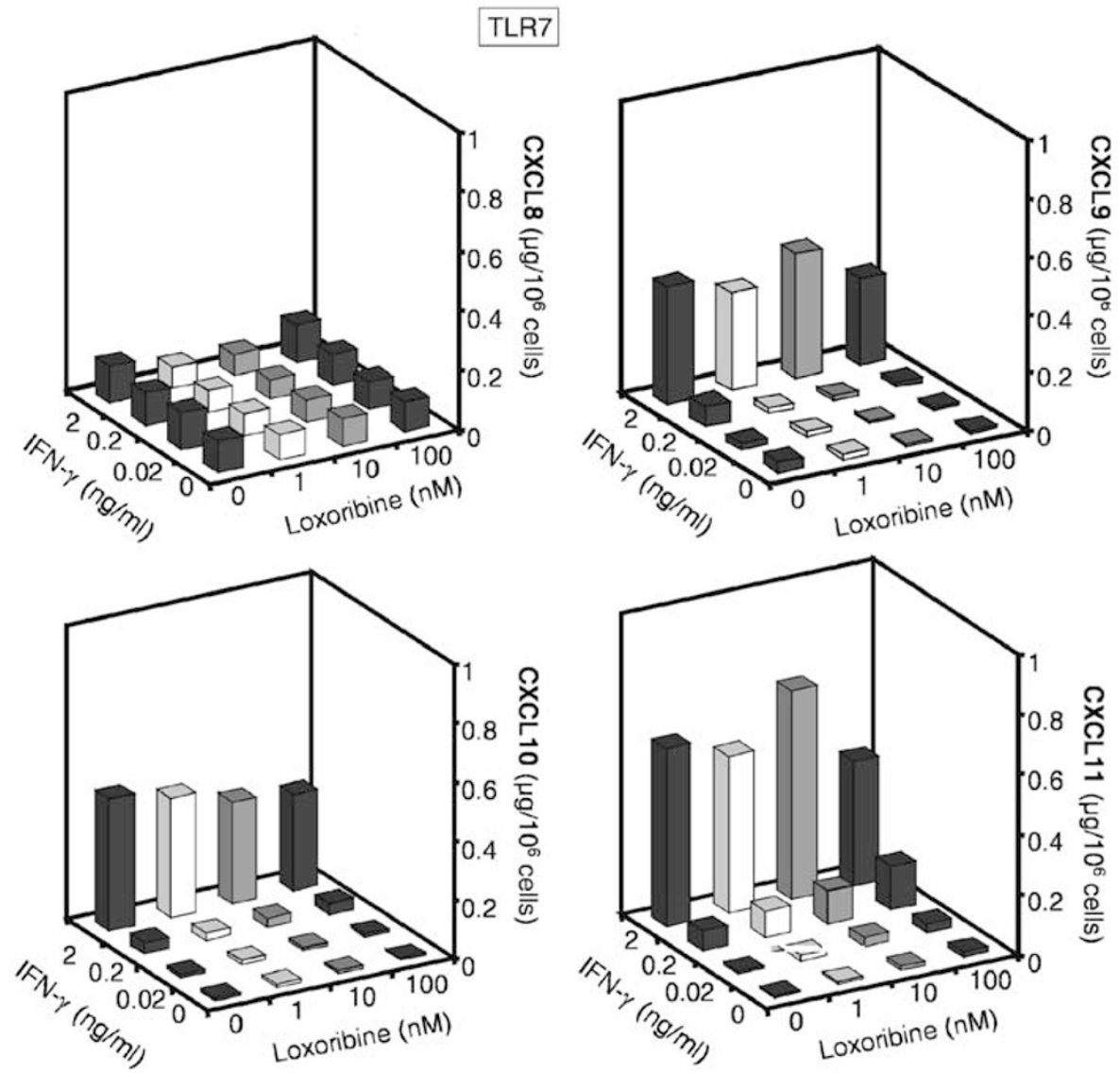

Figure 5 Differential induction of CXC chemokines in HMVEC by IFN- $\gamma$ in combination with a TLR7 ligand. HMVEC were cultured to confluency and incubated with IFN- $\gamma$ in combination with loxoribine for $72 \mathrm{~h}$. Results represent the mean CXCL8, CXCL9, CXCL10 and CXCL11 concentration measured in the culture supernatant (five or more independent experiments). For clarity, error bars were not depicted in the figure.

plus LPS (Figure 2). In contrast, $2 \mathrm{ng} / \mathrm{ml}$ of IFN- $\gamma$ only weakly synergized with $10 \mathrm{ng} / \mathrm{ml}$ of TNF- $\alpha$ to induce CXCL11 $\left(0.9 \mu \mathrm{g} / 10^{6}\right.$ cells $)$ in HMVEC $(P<0.05)$.

For comparison with HMVEC, fibroblasts were also treated with combinations of cytokines to evaluate CXCR3 ligand induction (Figure 8). A synergistic increase of the CXCL9 and CXCL11 production was observed after stimulating fibroblasts with IFN- $\gamma$ and TNF- $\alpha$ or IL- $1 \beta$. In contrast to CXCL9, CXCL11 was more potently induced by IFN$\gamma$ in combination with IL-1 $\beta$. Indeed, significant synergy was already obtained when fibroblasts were costimulated with $2 \mathrm{ng} / \mathrm{ml}$ of IFN- $\gamma$ and $0.1 \mathrm{ng} / \mathrm{ml}$ of IL-1 $\beta \quad(P<0.05)$ or with $200 \mathrm{ng} / \mathrm{ml}$ of IFN- $\gamma$ and $0.1 \mathrm{ng} / \mathrm{ml}$ of TNF- $\alpha(P<0.05)$. However, IFN $-\gamma$ in combination with $\mathrm{TNF}-\alpha$ was more efficient at inducing CXCL9 in fibroblasts, in accordance with earlier data on CXCL9 mRNA. ${ }^{39}$ This emerges a similar induction pattern as was observed in HMVEC. Nevertheless, much lower levels of CXCL9 and CXCL11 were measured in fibroblasts.

Out of all TLR ligands tested, only dsRNA was able to synergize with IFN- $\gamma$ to induce CXCL11 in HMVEC (Figure 4). Upon viral infection, IFN- $\alpha$ and IFN- $\beta$ are secreted by leukocytes and fibroblasts, respectively, in order to prevent viral replication in uninfected cells. For comparison with IFN- $\gamma$, we also evaluated the effect of TNF- $\alpha$ and IL-1 $\beta$ in combination with IFN- $\alpha$ or IFN- $\beta$ on the CXCL9 and CXCL11 production in HMVEC and fibroblasts (Figure 9 and data not shown). In HMVEC, IFN- $\alpha$ and IFN- $\beta$ were unable to induce CXCL9 (data not shown), but CXCL11 was significantly induced by $1000 \mathrm{U} / \mathrm{ml}$ of IFN- $\beta\left(0.6 \mu \mathrm{g} / 10^{6}\right.$ cells $)$. Both IFN- $\alpha$ and IFN- $\beta$ were found to be free of LPS contamination $\left(<2 \mathrm{pg} \mathrm{LPS} / 10^{6} \mathrm{U}\right.$ IFN). The combination of IL- $1 \beta$ with IFN- $\alpha$ or IFN- $\beta$ resulted in a marginal increase of CXCL9 production by HMVEC, whereas CXCL11 production was not enhanced. Significant synergy between TNF- $\alpha$ and IFN- $\alpha$ or IFN- $\beta$ was found for both CXCL9 and CXCL11 production in HMVEC. Indeed, $1000 \mathrm{U} / \mathrm{ml}$ of IFN- $\beta$ in combination with $10 \mathrm{ng} / \mathrm{ml}$ of TNF- $\alpha$ provoked a synergistic production of $1 \mu \mathrm{g} / 10^{6}$ cells of CXCL11 $(P<0.05)$. In fibroblasts, these cytokines were unable to induce CXCL9 (data not shown). CXCL11 production, however, was synergistically enhanced after cotreatment of $1000 \mathrm{U} / \mathrm{ml}$ of IFN- $\beta$ with TNF- $\alpha$ or IL- $1 \beta$ $(P<0.05)$ (Figure 9). Comparable results were obtained in fibroblasts stimulated with IFN- $\alpha$ in combination with IL-1 $\beta$ (data not shown). 


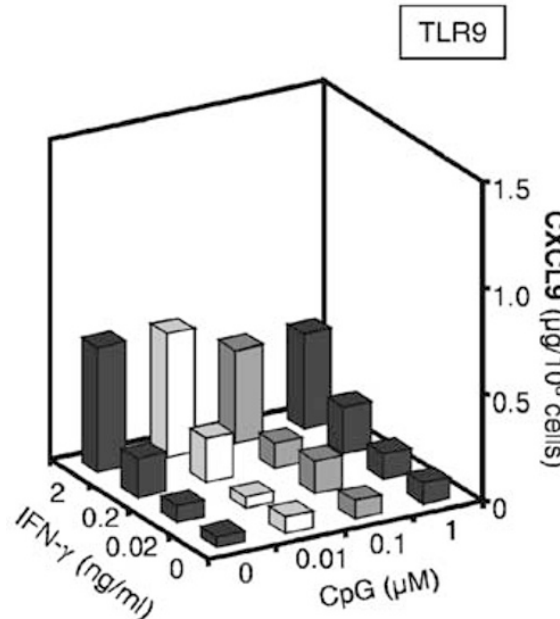

\section{TLR9 Co}
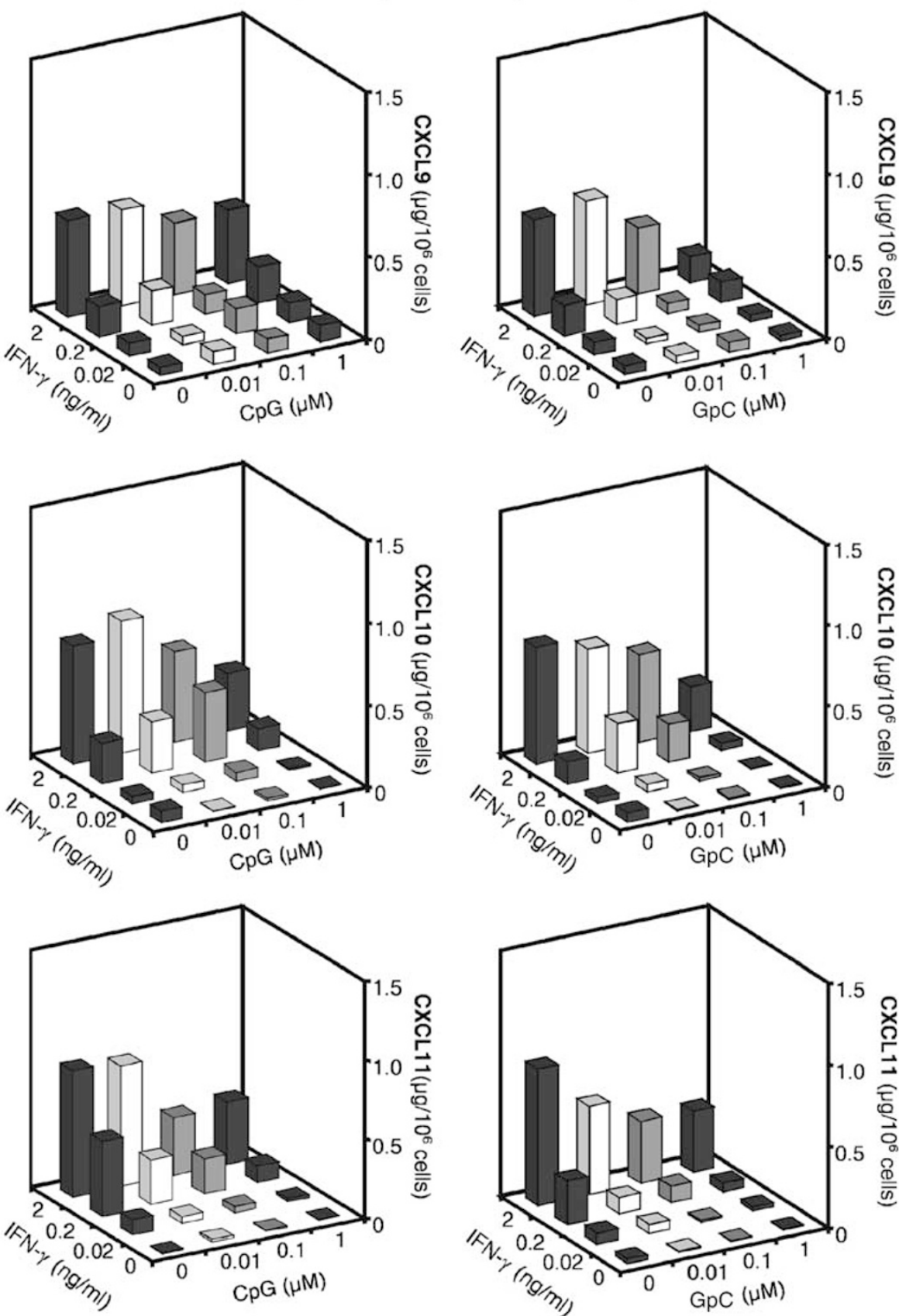

Figure 6 Differential induction of CXCR3 ligands in HMVEC by IFN- $\gamma$ in combination with a TLR9 ligand. Results represent the mean CXCL9, CXCL10 and CXCL11 concentration measured in the culture supernatant after incubating HMVEC for $72 \mathrm{~h}$ with IFN- $\gamma$ in combination with unmethylated CpG or GpC oligonucleotide (four or more independent experiments), marked by TLR9 and TLR9 Co, respectively, in the figure. For clarity, error bars were not depicted in the figure.

Synergistic Production of CXCL9 in HMVEC Provoked by TLR2 and TLR4 Ligands in Combination with IFN- $\gamma$ does not Depend on TNF- $\alpha$ or IL-1 $\beta$

To investigate whether the observed synergy after costimulation of HMVEC with IFN $-\gamma$ and LPS or PGN was indirectly caused by TNF- $\alpha$ or IL- $1 \beta$, Etanercept, a neutralizing agent of TNF- $\alpha$ (Figure 10 ), or a neutralizing monoclonal anti-human IL-1 $\beta$ antibody, respectively, were added to the cultures. The CXCL9 synergy provoked by the tested TLR ligands, LPS or PGN, was not inhibited by $250 \mathrm{ng} / \mathrm{ml}$ of Etanercept (Figure 10) nor by the anti-human IL$1 \beta$ antibody (1/100 dilution, data not shown), although TNF- $\alpha$ - or IL- $1 \beta$-induced CXCL8 production was significantly neutralized. Moreover, the synergistic CXCL9 production by HMVEC stimulated with IFN- $\gamma$ plus TNF- $\alpha$ was inhibited by 

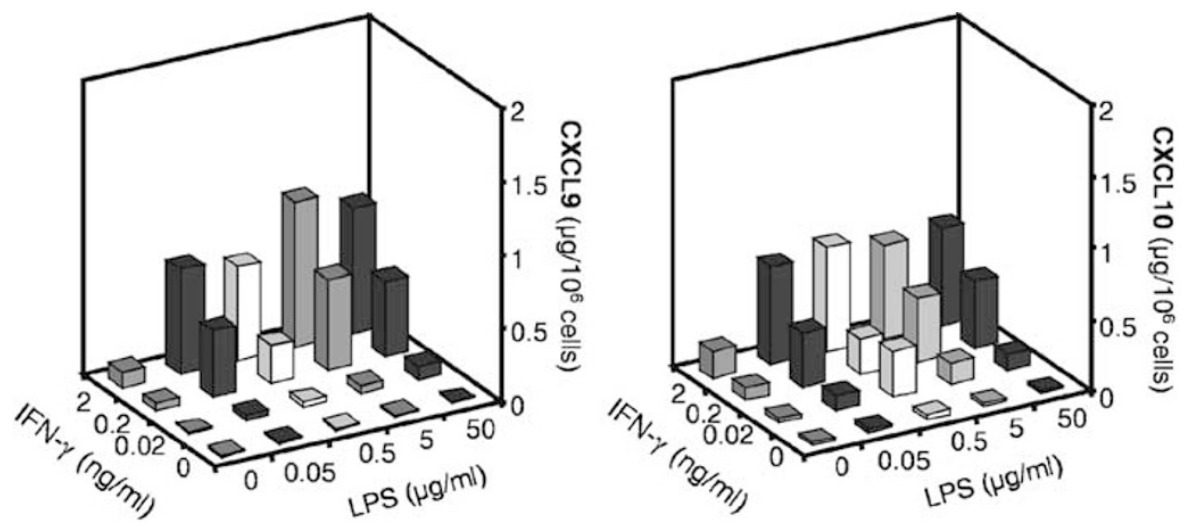

Figure 7 The TLR4 ligand directly interferes with the IFN- $\gamma$-dependent CXCR3 ligand induction in HMVEC. Confluent HMVEC were incubated for $24 \mathrm{~h}$ with IFN- $\gamma$ in combination with LPS. Results represent the mean CXCL9 and CXCL10 concentration measured in the culture supernatant (three or more independent experiments). For clarity, error bars were not depicted in the figure. A significant synergistic CXCL9 and CXCL10 induction $(P<0.05)$ was already observed at a concentration of $0.05 \mu \mathrm{g} / \mathrm{ml}$ of LPS combined with $2 \mathrm{ng} / \mathrm{ml}$ of IFN- $\gamma$.

Etanercept $(P<0.05)$. CXCL9 production decreased to the production level on IFN- $\gamma$-treated HMVEC cultures (Figure 10). Etanercept on itself was unable to induce CXCL9 nor did it affect the IFN- $\gamma$ stimulated CXCL9 production in HMVEC (data not shown).

\section{Differential Expression of CXCL9 and CXCL11 in Rheumatic Diseases}

In vivo administration of specific cytokine inhibitors is a valuable treatment of chronic inflammatory diseases. Neutralization of TNF- $\alpha$ activity with Etanercept or antibodies, for example, infliximab and adalimumab, is beneficial for most of the patients with rheumatoid diseases as it not only inhibits TNF- $\alpha$ activity, but also the production of IL-1 and other proinflammatory cytokines ${ }^{40,41}$ Moreover, in a murine model for spondylarthropathies, IFN- $\gamma$ has been reported to play a prominent role in view of the fact that the incidence of arthritis was significantly reduced in IFN- $\gamma$ receptor knockout mice. ${ }^{42}$ As these cytokines synergistically induced CXCL9 and CXCL11 in HMVEC and fibroblasts (Figure 8), synovial fluids from patients with rheumatic disorders were analyzed for the amount of CXCL9 and CXCL11. The patients were diagnosed with ankylosing spondylitis, psoriatic arthritis, crystal-induced arthritis or rheumatoid arthritis. A significant increase of CXCL9 median levels in the synovial fluid was observed in autoimmune arthritis patients (ankylosing spondylitis, psoriatic arthritis and rheumatoid arthritis) compared to crystal- induced arthritis (Figure 11). In contrast, none of the groups of autoimmune arthritis patients had higher CXCL11 median levels compared to crystalinduced arthritis. The median CXCL11 concentration was enhanced in rheumatoid arthritis in comparison with ankylosing spondylitis, but not compared to crystal-induced arthritis (Figure 11). No correlation was uncovered between CXCL9 or CXCL11 concentrations and erythrocyte sedimentation rates for the group of arthritis patients examined (data not shown).

\section{Discussion}

The innate immune system greatly relies on the conserved family of receptors for pathogen-associated molecular patterns (PAMPs), which recognize a series of microbial components and initiate an immune response through, for example, TLR. To date, 10 human TLR have been identified. TLR1, 2, 4, 5 and 6 are expressed on cell surfaces and cover bacterial recognition, whereas TLR3, 7, 8 and 9 are found in intracellular compartments and detect nucleic acids, including dsRNA, single-stranded RNA and unmethylated CpG oligonucleotides. ${ }^{20,43,44}$ Besides microbial compounds, TLR also recognize endogenous components (eg fibronectin fragments) and TLR activation enhances B-cell responses, indicative for their possible role in the pathogenesis of autoimmune diseases. ${ }^{22-25}$

Several publications show chemokine induction by single TLR ligands in a number of cell types. ${ }^{27,28,45-49}$ In fibroblasts and PBMC, IFN- $\gamma$ and

Figure 8 Differential induction of CXCL9 and CXCL11 in HMVEC and fibroblasts by IFN- $\gamma$ in combination with IL-1 $\beta$ or TNF- $\alpha$. Confluent HMVEC (upper four panels) and fibroblasts (lower four panels) were incubated for $72 \mathrm{~h}$ with IFN- $\gamma$ in combination with IL- $1 \beta$ or TNF- $\alpha$. Results represent the mean CXCL9 and CXCL11 concentration measured in the culture supernatant (three or more independent experiments). For clarity, error bars were not depicted in the figure. Significant synergistic induction of CXCL9 and CXCL11 in both cell types was observed for the highest doses of IL-1 $\beta$ and TNF- $\alpha$ tested $(P<0.05$ or lower). 

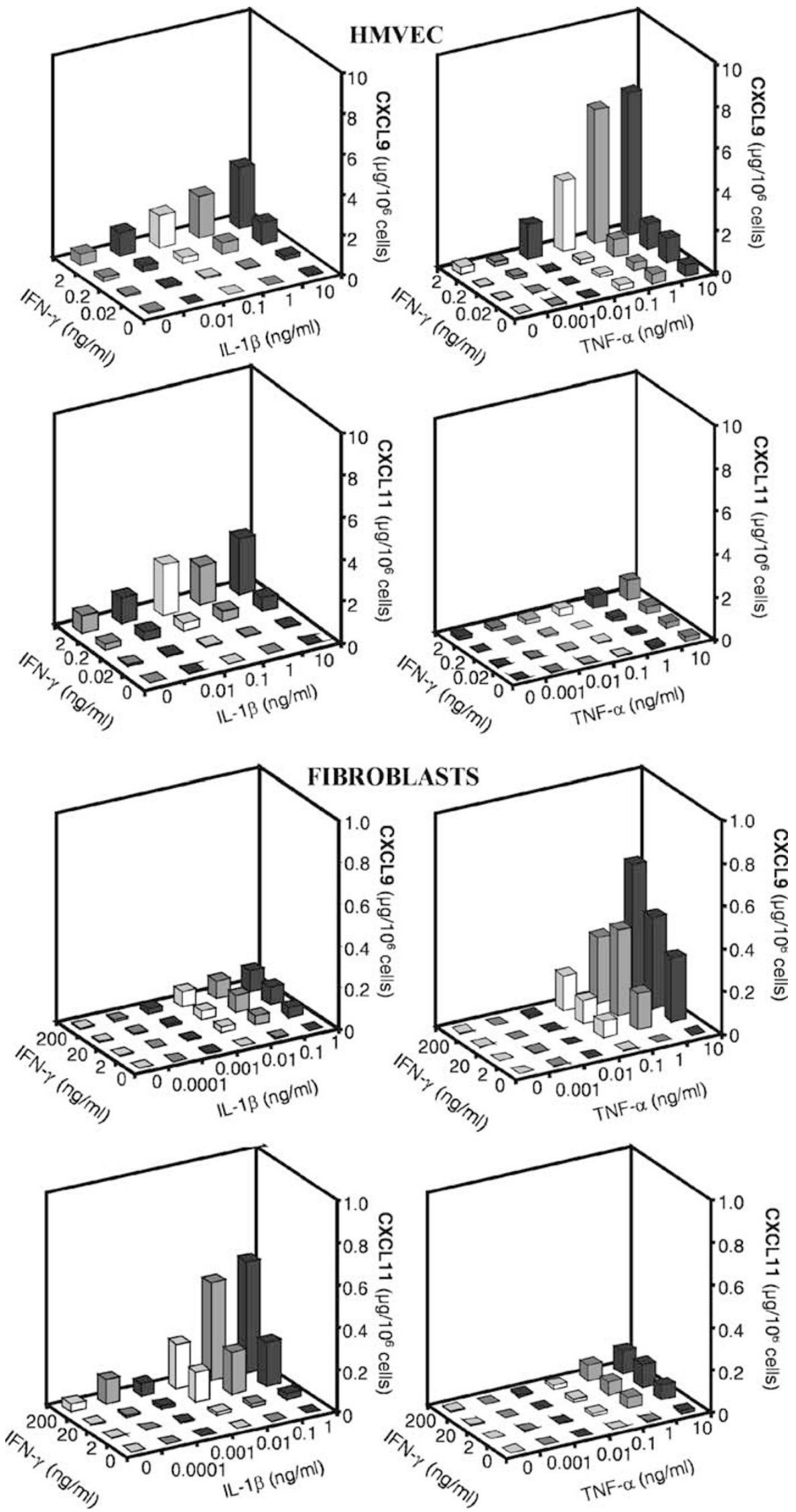
dsRNA were potent inducers of CXCR3 ligands. ${ }^{27,28}$ Moreover, synergy was observed when fibroblasts were stimulated with a combination of TLR2, 3, 4 or 5 ligands and the Th1 cytokine IFN- $\gamma$. In contrast, in PBMC, the combination of IFN- $\gamma$ and PGN or LPS provoked a decrease of CXCR3 ligand production, whereas dsRNA and flagellin did not significantly alter IFN- $\gamma$-dependent CXCL9 and CXCL11 production. Thus, chemokine production is differentially regulated, depending on the cellular source and the presence of different cytokines. ${ }^{50}$ In general, PBMC were less potent producers of CXCR3 agonists compared to fibroblasts, but superior producers of CXCL8. ${ }^{27,28}$

In this paper, we show that HMVEC are important producers of CXC chemokines in response to microbial infection. Bacterial PGN and LPS were found to enhance the IFN- $\gamma$-dependent production of CXCL9 and CXCL10. Conversely, bacterial flagellin was unable to alter the chemokine production levels in HMVEC. CXCL8, on the other hand, was induced by PGN and LPS, but no synergy was obtained when IFN- $\gamma$ was added. Nonetheless, these results show that HMVEC release high amounts of CXCL9 and CXCL10 under conditions mimicking bacterial infection or inflammation compared to production levels of CXCL9 or CXCL10 in PBMC. ${ }^{27,28}$ Remarkably, CXCL11 production by HMVEC was not changed by the addition of the bacterial components tested. However, a synergistic effect was observed for CXCL11 when HMVEC were treated with dsRNA and IFN- $\gamma$. Furthermore, this synergistic production of CXCL11 was comparable to that of CXCL9 and CXCL10. As CXCL11 has the highest specific activity on CXCR3, CXCL11 may play a pivotal role during infection with RNA viruses. The TLR3 ligand dsRNA induced CXCL8, but no synergistic CXCL8 production was observed upon co-treatment of HMVEC with IFN- $\gamma$. Nevertheless, the amounts of CXCL8 and CXCR3 ligands which were induced by dsRNA, with or without IFN- $\gamma$, were again much higher in HMVEC compared to PBMC, indicative for the crucial role of HMVEC for CXC chemokine production during viral infection. Such high amounts of CXCR3 ligands, and in particular CXCL9, have been reported to exhibit direct receptor-independent defensin-like anti-microbial properties. ${ }^{51}$ The recognition of a single receptor (CXCR3) by multiple chemokines, that is, redundancy of chemokines, may be biologically
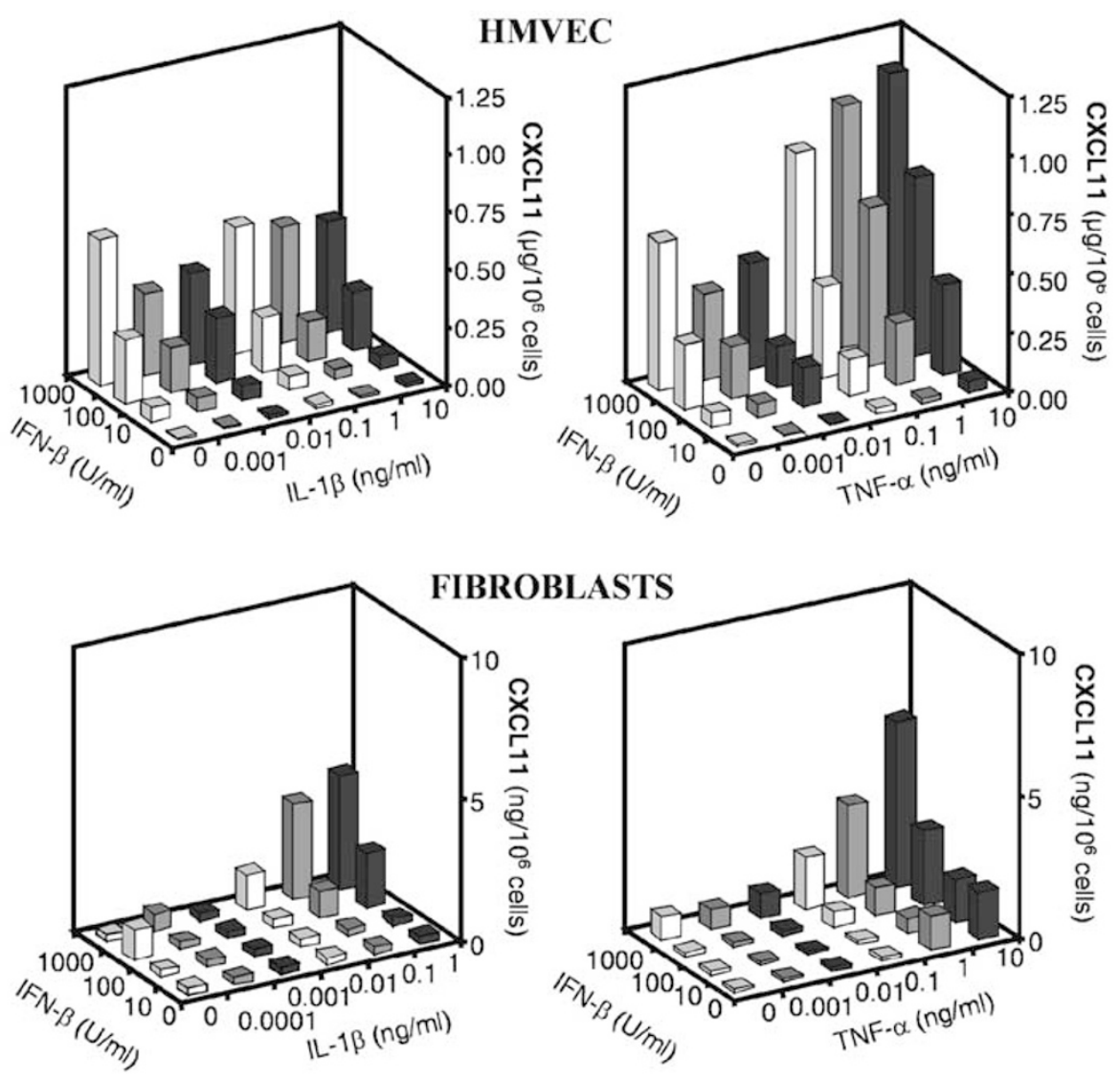

Figure 9 Differential induction of CXCL11 in HMVEC and fibroblasts by IL- $1 \beta$ or TNF- $\alpha$ in combination with IFN- $\beta$. Results represent the mean CXCL11 concentration measured in the culture supernatant after incubating confluent HMVEC (upper panels) or fibroblasts (lower panels) for $72 \mathrm{~h}$ with IL- $1 \beta$ or TNF- $\alpha$ in combination with IFN- $\beta$ (three or more independent experiments). For clarity, error bars were not depicted in the figure. Significant synergistic induction of CXCL11 was obtained at $1000 \mathrm{U} / \mathrm{ml}$ of IFN- $\beta$ in combination with $10 \mathrm{ng} / \mathrm{ml}$ of TNF- $\alpha$ in HMVEC $(P<0.05)$ and in combination with $10 \mathrm{ng} / \mathrm{ml}$ of TNF- $\alpha$ or $1 \mathrm{ng} / \mathrm{ml}$ of IL- $1 \beta$ in fibroblasts $(P<0.05)$. 


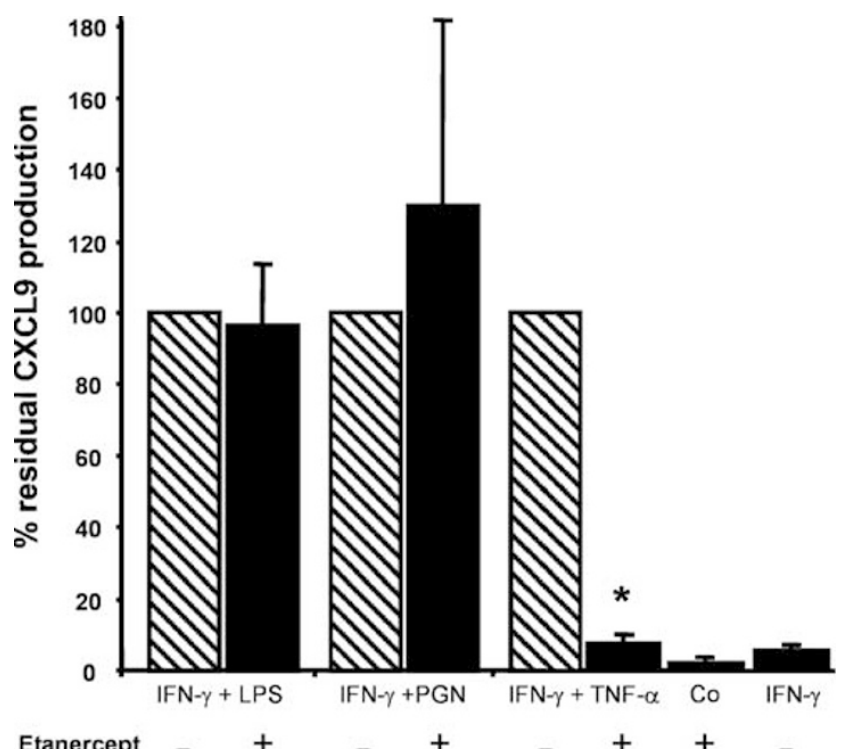

Figure 10 Synergistic production of CXCL9 in HMVEC provoked by TLR2 and TLR4 ligands in combination with IFN- $\gamma$ is not mediated by TNF- $\alpha$. HMVEC were cultured to confluency and incubated for $72 \mathrm{~h}$ with $0.2 \mathrm{ng} / \mathrm{ml}$ of IFN- $\gamma$ in combination with $5 \mu \mathrm{g} / \mathrm{ml}$ of LPS, $0.2 \mathrm{ng} / \mathrm{ml}$ of IFN- $\gamma$ plus $10 \mu \mathrm{g} / \mathrm{ml}$ of PGN, $0.2 \mathrm{ng} / \mathrm{ml}$ of IFN- $\gamma$ plus $1 \mathrm{ng} / \mathrm{ml}$ of TNF- $\alpha$, were left untreated (Co) or were stimulated with $0.2 \mathrm{ng} / \mathrm{ml}$ of IFN- $\gamma$ alone, in the presence $(+)$ or absence (-) of $250 \mathrm{ng} / \mathrm{ml}$ of Etanercept. Etanercept and inducers were administrated simultaneously. Results (filled bars \pm s.e.m.) represent the percentage residual CXCL9 protein concentration measured in the culture supernatant (four independent experiments) compared to the synergistic CXCL9 production $(100 \%$, dashed bars) when no Etanercept was added to the inducers $\left({ }^{*} P<0.05\right)$. Statistical analysis was performed using the MannWhitney test. Untreated and IFN- $\gamma$-treated HMVEC were compared with HMVEC stimulated with IFN- $\gamma$ plus TNF- $\alpha$ without Etanercept.

explained by our results. Under specific conditions, for example, viral vs bacterial infections, induction of particular ligands by specific producer cells may regulate fine tuning of the response. This fine tuning is critical, since chemotactic factors can also synergize. ${ }^{50}$ As a consequence, biological responses needed for eradication of bacterial infections, may be unwanted in the case of viral diseases. This biological response may, therefore, also be relevant in the case of autoimmune diseases.

In contrast to the aforementioned observations, loxoribine, a TLR7 ligand, was unable to induce CXCL8 or CXCR3 ligands nor did it alter the IFN- $\gamma$ dependent production of CXCL9, CXCL10 and CXCL11 in HMVEC. These findings on HMVEC run parallel with a recent publication suggesting that TLR7 is not expressed on HUVEC, ${ }^{19}$ which we confirmed by RT-PCR (data not shown). The TLR9 ligand, unmethylated $\mathrm{CpG}$ oligonucleotide, on the other hand, was found to inhibit CXCR3 ligand production. However, the control unmethylated GpC oligonucleotide also decreased the IFN- $\gamma$ dependent induction of CXCL9, CXCL10 and CXCL11 and no TLR9 expression on HMVEC was
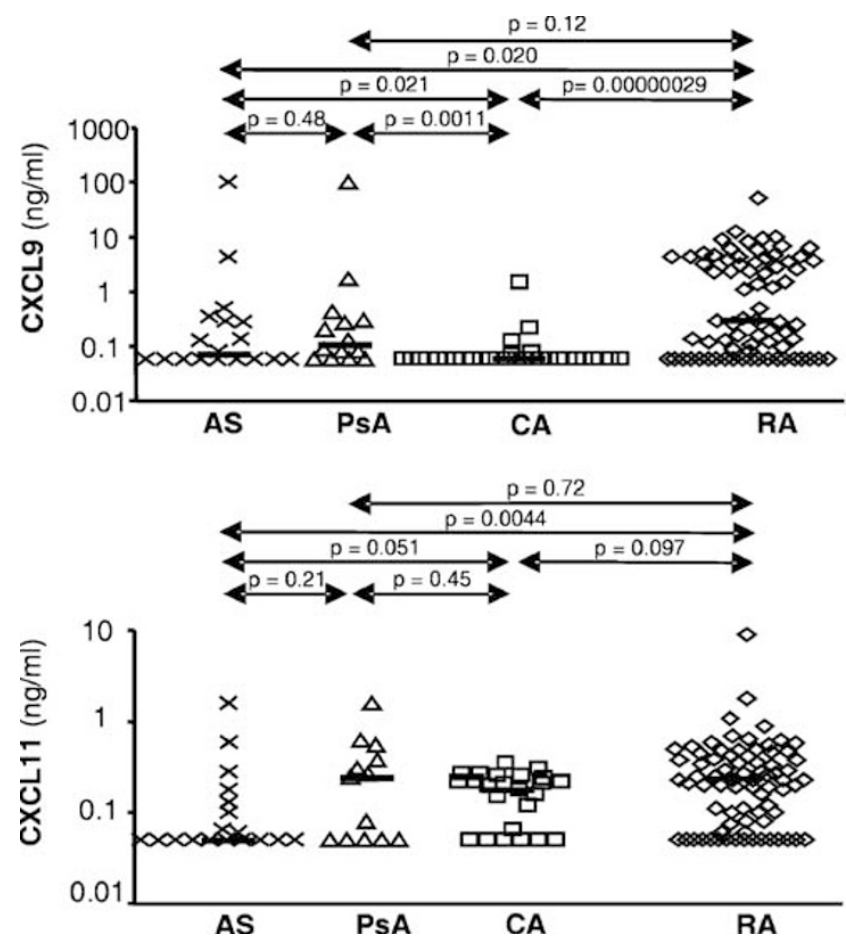

Figure 11 Differential expression of CXCL9 and CXCL11 in rheumatic diseases. CXCL9 and CXCL11 concentrations were measured by ELISA in synovial fluids of patients with autoimmune ankylosing spondylitis (AS), psoriatic arthritis (PsA) or rheumatoid arthritis (RA) and compared to previously reported ${ }^{28}$ chemokine concentrations in patients with metabolic crystalinduced arthritis (CA). Statistical analysis was performed with the median levels (horizontal bars) using the Mann-Whitney test. Chemokine concentrations are indicated on a logarithmic $Y$-axis.

detected by RT-PCR (data not shown), suggesting that the mechanism responsible for this inhibitory effect is not TLR9-mediated. Recently, also neutrophils and macrophages have been reported to be activated by DNA in a TLR9-independent manner. ${ }^{52,53}$

In the process of TLR ligand recognition and signaling, endogenous cytokines are upregulated, which can indirectly induce a number of chemokines. TNF- $\alpha$ and IL- $1 \beta$, which are highly upregulated by LPS, were found to increase the IFN- $\gamma$ dependent CXCL9 and CXCL11 production in HMVEC. These results were in line with published data in HUVEC. ${ }^{54}$ Such synergy was also observed when we stimulated fibroblasts with TNF- $\alpha$ or IL- $1 \beta$ in combination with IFN- $\gamma$. TNF- $\alpha$ was also able to synergize with IFN- $\beta$ for CXCL9 and CXCL11 production in HMVEC, whereas in fibroblasts, synergistic production of CXCL11, but not CXCL9, was observed when the cells were cotreated with IL$1 \beta$ and type I IFNs. A synergistic effect was also observed for CXCL8 (data not shown) when HMVEC were stimulated with IL- $1 \alpha$ and IFN- $\gamma \cdot{ }^{38}$ Other publications reported rather an additive effect when TNF- $\alpha$ was a stimulating agent, ${ }^{38,54}$ although this effect was endothelial cell type-dependent accord- 
ing to Hillyer et al. ${ }^{55}$ Interestingly, the observed CXCL9 synergy between IFN- $\gamma$ and the TLR ligands LPS or PGN, was not mediated by TNF- $\alpha$ or IL-1 $\beta$. Thus, interaction of microbial or endogenous TLR ligands with endogenous cytokines and cytokine combinations can initiate an excessive production of CXCR3 ligands and CXCL8, which in turn will attract Th1 lymphocytes, NK cells and neutrophils to the inflammatory site.

In the synovial cavity, a larger population of fibroblasts is present in comparison with endothelial cells. However, the overall amount of chemokine induced in HMVEC was much higher than in fibroblasts, indicating that both cell types are important in creating the chemokine spectrum in the synovial cavity. Hence, we examined the amount of chemokines present in synovial fluids of patients with rheumatic diseases. We observed that CXCL9, but not CXCL11, production was significantly increased in all three autoimmune arthritis populations, that is, ankylosing spondylitis, psoriatic arthritis and rheumatoid arthritis, compared to crystal-induced arthritis. The results are in line with the induction experiments in which ligands for TLR2 and TLR4, the TLR receptors that are activated by, for example, hyaluronan oligosaccharides and necrotic cells, ${ }^{23,24,56-59}$ are potent enhancers of CXCL9, but not CXCL11, production. Taken together, these findings strengthen the importance of the discussion whether TLR and their signaling pathways should be investigated as potential drug targets in the treatment of chronic inflammatory disorders.

\section{Acknowledgements}

This work was supported by the Fund for Scientific Research of Flanders (FWO-Vlaanderen), the Concerted Research Actions (GOA) of the Regional Government of Flanders, the Inter University Attraction Poles Programme-Belgian Science Policy (IUAP), the European Union 6FP EC contract INNOCHEM and the Center of Excellence of the KU Leuven (Credit no. EF/05/15). PP, SS and ES are senior research assistants of the FWO-Vlaanderen.

\section{Duality of interest}

None declared.

\section{References}

1 Murphy PM. International Union of Pharmacology. XXX. Update on chemokine receptor nomenclature. Pharmacol Rev 2002;54:227-229.

2 Zlotnik A, Yoshie O. Chemokines: a new classification system and their role in immunity. Immunity 2000;12:121-127.
3 Mantovani A, Sica A, Sozzani S, et al. The chemokine system in diverse forms of macrophage activation and polarization. Trends Immunol 2004;25:677-686.

4 Moser B, Wolf M, Walz A, et al. Chemokines: multiple levels of leukocyte migration control. Trends Immunol 2004;25:75-84.

5 Sallusto F, Mackay CR. Chemoattractants and their receptors in homeostasis and inflammation. Curr Opin Immunol 2004;16:724-731.

6 Sozzani S. Dendritic cell trafficking: More than just chemokines. Cytokine Growth Factor Rev 2005;16: 581-592.

7 Rot A, von Andrian UH. Chemokines in innate and adaptive host defense: basic chemokinese grammar for immune cells. Annu Rev Immunol 2004;22:891-928.

8 Proost P, Wuyts A, Van Damme J. The role of chemokines in inflammation. Int J Clin Lab Res 1996;26:211-223.

9 Strieter RM, Belperio JA, Burdick MD, et al. CXC chemokines in angiogenesis relevant to chronic fibroproliferation. Curr Drug Targets Inflamm Allergy 2005; $4: 23-26$.

10 Struyf S, Burdick MD, Proost P, et al. Platelets release CXCL4L1, a nonallelic variant of the chemokine platelet factor-4/CXCL4 and potent inhibitor of angiogenesis. Circ Res 2004;95:855-857.

11 Godessart N, Kunkel SL. Chemokines in autoimmune disease. Curr Opin Immunol 2001;13:670-675.

12 Strieter RM, Belperio JA, Phillips RJ, et al. CXC chemokines in angiogenesis of cancer. Semin Cancer Biol 2004;14:195-200.

13 Christopherson II KW, Hromas RA. Endothelial chemokines in autoimmune disease. Curr Pharm Des 2004;10:145-154.

14 Presta M, Leali D, Stabile H, et al. Heparin derivatives as angiogenesis inhibitors. Curr Pharm Des 2003;9: 553-566.

15 Bernardini G, Ribatti D, Spinetti G, et al. Analysis of the role of chemokines in angiogenesis. J Immunol Methods 2003;273:83-101.

16 Faure E, Equils O, Sieling PA, et al. Bacterial lipopolysaccharide activates NF-kappaB through tolllike receptor 4 (TLR-4) in cultured human dermal endothelial cells. Differential expression of TLR-4 and TLR-2 in endothelial cells. J Biol Chem 2000;275: 11058-11063.

17 Li J, Ma Z, Tang ZL, et al. CpG DNA-mediated immune response in pulmonary endothelial cells. Am J Physiol Lung Cell Mol Physiol 2004;287:L552-L558.

18 Maaser C, Heidemann J, von Eiff C, et al. Human intestinal microvascular endothelial cells express Tolllike receptor 5: a binding partner for bacterial flagellin. J Immunol 2004;172:5056-5062.

19 Tissari J, Siren J, Meri S, et al. IFN-alpha enhances TLR3-mediated antiviral cytokine expression in human endothelial and epithelial cells by up-regulating TLR3 expression. J Immunol 2005;174:4289-4294.

20 Takeda K, Akira S. Toll-like receptors in innate immunity. Int Immunol 2005;17:1-14.

21 Liew FY, Xu D, Brint EK, et al. Negative regulation of toll-like receptor-mediated immune responses. Nat Rev Immunol 2005;5:446-458.

22 Andreakos E, Foxwell B, Feldmann M. Is targeting Toll-like receptors and their signaling pathway a useful therapeutic approach to modulating cytokinedriven inflammation? Immunol Rev 2004;202: 250-265. 
23 Smiley ST, King JA, Hancock WW. Fibrinogen stimulates macrophage chemokine secretion through tolllike receptor 4. J Immunol 2001;167:2887-2894.

24 Termeer C, Benedix F, Sleeman J, et al. Oligosaccharides of Hyaluronan activate dendritic cells via toll-like receptor 4. J Exp Med 2002;195:99-111.

25 Pasare C, Medzhitov R. Control of B-cell responses by Toll-like receptors. Nature 2005;438:364-368.

26 Akira S, Hemmi H. Recognition of pathogen-associated molecular patterns by TLR family. Immunol Lett 2003; 85:85-95.

27 Proost P, Vynckier AK, Mahieu F, et al. Microbial Tolllike receptor ligands differentially regulate CXCL10/ IP-10 expression in fibroblasts and mononuclear leukocytes in synergy with IFN-gamma and provide a mechanism for enhanced synovial chemokine levels in septic arthritis. Eur J Immunol 2003;33:3146-3153.

28 Proost P, Verpoest S, Van de Borne K, et al. Synergistic induction of CXCL9 and CXCL11 by Toll-like receptor ligands and interferon-gamma in fibroblasts correlates with elevated levels of CXCR3 ligands in septic arthritis synovial fluids. J Leukoc Biol 2004;75: 777-784.

29 Proost P, De Wolf-Peeters C, Conings R, et al. Identification of a novel granulocyte chemotactic protein (GCP-2) from human tumor cells. In vitro and in vivo comparison with natural forms of GRO, IP-10, and IL-8. J Immunol 1993;150:1000-1010.

30 Goebeler M, Yoshimura T, Toksoy A, et al. The chemokine repertoire of human dermal microvascular endothelial cells and its regulation by inflammatory cytokines. J Invest Dermatol 1997;108:445-451.

31 Luster AD, Ravetch JV. Genomic characterization of a gamma-interferon-inducible gene (IP-10) and identification of an interferon-inducible hypersensitive site. Mol Cell Biol 1987;7:3723-3731.

32 Yoshimura A, Lien E, Ingalls RR, et al. Cutting edge: recognition of Gram-positive bacterial cell wall components by the innate immune system occurs via Tolllike receptor 2. J Immunol 1999;163:1-5.

33 Hoshino K, Takeuchi O, Kawai T, et al. Cutting edge: Toll-like receptor 4 (TLR4)-deficient mice are hyporesponsive to lipopolysaccharide: evidence for TLR4 as the Lps gene product. J Immunol 1999;162:3749-3752.

34 Hayashi F, Smith KD, Ozinsky A, et al. The innate immune response to bacterial flagellin is mediated by Toll-like receptor 5. Nature 2001;410:1099-1103.

35 Alexopoulou L, Holt AC, Medzhitov R, et al. Recognition of double-stranded RNA and activation of NF-kappaB by Toll-like receptor 3. Nature 2001;413: 732-738.

36 Heil F, Ahmad-Nejad P, Hemmi H, et al. The Toll-like receptor 7 (TLR7)-specific stimulus loxoribine uncovers a strong relationship within the TLR7, 8 and 9 subfamily. Eur J Immunol 2003;33:2987-2997.

37 Hemmi H, Takeuchi O, Kawai T, et al. A Toll-like receptor recognizes bacterial DNA. Nature 2000;408: 740-745.

38 Brown Z, Gerritsen ME, Carley WW, et al. Chemokine gene expression and secretion by cytokine-activated human microvascular endothelial cells. Differential regulation of monocyte chemoattractant protein-1 and interleukin-8 in response to interferon-gamma. Am J Pathol 1994;145:913-921.

39 Ohmori Y, Schreiber RD, Hamilton TA. Synergy between interferon-gamma and tumor necrosis factoralpha in transcriptional activation is mediated by cooperation between signal transducer and activator of transcription 1 and nuclear factor kappaB. J Biol Chem 1997;272:14899-14907.

40 Tak PP. Effects of infliximab treatment on rheumatoid synovial tissue. J Rheumatol Suppl 2005;74:31-34.

41 Taylor PC, Williams RO, Feldmann M. Tumour necrosis factor alpha as a therapeutic target for immune-mediated inflammatory diseases. Curr Opin Biotechnol 2004;15:557-563.

42 Matthys P, Lories RJ, De Klerck B, et al. Dependence on interferon-gamma for the spontaneous occurrence of arthritis in DBA/1 mice. Arthritis Rheum 2003;48: 2983-2988.

43 Parker LC, Whyte MK, Dower SK, et al. The expression and roles of Toll-like receptors in the biology of the human neutrophil. J Leukoc Biol 2005;77:886-892.

44 Underhill DM. Toll-like receptors and microbes take aim at each other. Curr Opin Immunol 2004;16: 483-487.

45 Caron G, Duluc D, Fremaux I, et al. Direct stimulation of human T cells via TLR5 and TLR7/8: flagellin and R-848 up-regulate proliferation and IFN-gamma production by memory CD4+ T cells. J Immunol 2005;175: 1551-1557.

46 Kawai T, Takeuchi O, Fujita T, et al. Lipopolysaccharide stimulates the MyD88-independent pathway and results in activation of IFN-regulatory factor 3 and the expression of a subset of lipopolysaccharide-inducible genes. J Immunol 2001;167:5887-5894.

47 Oude Nijhuis CS, Vellenga E, Daenen SM, et al. Endothelial cells are main producers of interleukin 8 through Toll-like receptor 2 and 4 signaling during bacterial infection in leukopenic cancer patients. Clin Diagn Lab Immunol 2003;10:558-563.

48 Schaefer TM, Desouza K, Fahey JV, et al. Toll-like receptor (TLR) expression and TLR-mediated cytokine/chemokine production by human uterine epithelial cells. Immunology 2004;112:428-436.

49 Coelho AL, Hogaboam CM, Kunkel SL. Chemokines provide the sustained inflammatory bridge between innate and acquired immunity. Cytokine Growth Factor Rev 2005;16:553-560.

50 Gouwy M, Struyf S, Proost P, et al. Synergy in cytokine and chemokine networks amplifies the inflammatory response. Cytokine Growth Factor Rev 2005;16: $561-580$

51 Cole AM, Ganz T, Liese AM, et al. Cutting edge: IFN-inducible ELR- CXC chemokines display defensin-like antimicrobial activity. J Immunol 2001;167: 623-627.

52 Trevani AS, Chorny A, Salamone G, et al. Bacterial DNA activates human neutrophils by a CpG-independent pathway. Eur J Immunol 2003;33:3164-3174.

53 Okabe Y, Kawane K, Akira S, et al. Toll-like receptorindependent gene induction program activated by mammalian DNA escaped from apoptotic DNA degradation. J Exp Med 2005;202:1333-1339.

54 Piali L, Weber C, LaRosa G, et al. The chemokine receptor CXCR3 mediates rapid and shear-resistant adhesion-induction of effector $\mathrm{T}$ lymphocytes by the chemokines IP10 and Mig. Eur J Immunol 1998; 28:961-972.

55 Hillyer P, Mordelet E, Flynn G, et al. Chemokines, chemokine receptors and adhesion molecules on different human endothelia: discriminating the tissue-specific functions that affect leucocyte migration. Clin Exp Immunol 2003;134:431-441. 
56 Kyburz D, Rethage J, Seibl R, et al. Bacterial peptidoglycans but not CpG oligodeoxynucleotides activate synovial fibroblasts by toll-like receptor signaling. Arthritis Rheum 2003;48:642-650.

$57 \mathrm{Li} \mathrm{M}$, Carpio DF, Zheng Y, et al. An essential role of the NF-kappa B/Toll-like receptor pathway in induction of inflammatory and tissue-repair gene expression by necrotic cells. J Immunol 2001;166: 7128-7135.
58 Seibl R, Birchler T, Loeliger S, et al. Expression and regulation of Toll-like receptor 2 in rheumatoid arthritis synovium. Am J Pathol 2003;162:1221-1227.

59 De Rycke L, Vandooren B, Kruithof E, et al. Tumor necrosis factor alpha blockade treatment downmodulates the increased systemic and local expression of Toll-like receptor 2 and Toll-like receptor 4 in spondylarthropathy. Arthritis Rheum 2005;52: 2146-2158.

Supplementary Information accompanies the paper on the Laboratory Investigation website (http:// www.nature.com/labinvest) 